\title{
Relationship between physiological traits and yield of rice (Oryza sativa L.) under modified system of rice intensification
}

\author{
S. Mohan Kumar* \\ Agro Climate Research Centre, Tamil Nadu Agricultural University, Coimbatore - 641003 \\ (Tamil Nadu), India \\ N. Thavaprakaash \\ Department of Agronomy, Tamil Nadu Agricultural University, Coimbatore - 641003 \\ (Tamil Nadu), India
}

*Corresponding author. Email: psmohan13@gmail.com

\section{Article Info}

https://doi.org/10.31018/ jans.v13iSI.2771

Received: March 22, 2021

Revised: April 17, 2021

Accepted: May 8, 2021

\section{How to Cite}

Mohan Kumar, S. and Thavaprakaash, N. (2021). Relationship between physiological traits and yield of rice (Oryza sativa L.) under modified system of rice intensification. Journal of Applied and Natural Science, 13 (SI), 9 - 17. https://doi.org/10.31018/ jans.v13iSI.2771

\begin{abstract}
A field experiment was conducted to study influence of high-density planting on physiological parameters and yield of rice during late Samba (September-January) season of 2018-19. The treatments comprised of $T_{1}-25 \times 25 \mathrm{~cm}$ with $100 \%$ Recommended Dose of Fertilizer (RDF) (SRI), $T_{2}-25 \times 20 \mathrm{~cm}$ with $100 \%$ RDF, $\mathrm{T}_{3}-25 \times 15 \mathrm{~cm}$ with $100 \%$ RDF, $\mathrm{T}_{4}-25 \times 15 \mathrm{~cm}$ with $125 \%$ RDF, $T_{5}-20 \times 20 \mathrm{~cm}$ with $100 \%$ RDF, $T_{6}-20 \times 15 \mathrm{~cm}$ with $100 \%$ RDF, $T_{7}-20 \times 15 \mathrm{~cm}$ with $125 \%$ RDF and $\mathrm{T}_{8}$ - Conventional cultivation with $100 \%$ RDF. Physiological parameters were recorded at four critical stages (active tillering, panicle initiation, flowering and maturity stages) of rice. The results revealed that photosynthetic rate $\left(\mu \mathrm{mol} \mathrm{CO}_{2} / \mathrm{m}^{2} / \mathrm{s}\right)$, transpiration rate $\left(\mathrm{mmol} \mathrm{H}_{2} \mathrm{O} /\right.$ $\mathrm{m}^{2} / \mathrm{s}$ ), stomatal conductance $\left(\mathrm{mol} \mathrm{H}_{2} \mathrm{O} / \mathrm{m}^{2} / \mathrm{s}\right.$ ) and chlorophyll index were increased in rice planted at a row spacing of $25 \mathrm{~cm}\left(\mathrm{~T}_{1}\right.$, $T_{2}$ and $T_{3}$ ) over other treatments in all the stages. Lower rates were noted in conventional method of planting $\left(T_{8}\right)$ followed by $T_{6}$ and $T_{7}$. During $0600 \mathrm{hrs}$ and $1000 \mathrm{hrs}$, closer spacing levels $\left(T_{5}, T_{6}, T_{7}\right.$ and $\left.T_{8}\right)$ had higher leaf temperature, while during later at $1400 \mathrm{hrs}$ and $1800 \mathrm{hrs}$, warmer leaf temperature $\left({ }^{\circ} \mathrm{C}\right)$ was noted in wider spacing levels $\left(\mathrm{T}_{1}\right.$ and $\left.\mathrm{T}_{2}\right)$ during all time of weekly observation. The grain yield of rice was higher with $20 \times 20 \mathrm{~cm}$ spacing level compared to other closer and wider spacing levels with either $100 \%$ or $125 \%$ RDF. By correlation analysis, all parameter had a significant influence on yield.
\end{abstract}

Keywords: Chlorophyll index, High density planting, Leaf temperature, Photosynthetic rate, Rice, Stomatal conductance, Transpiration rate

\section{INTRODUCTION}

Rice (Oryza sativa L.) is India's pre-eminent crop and the most important edible starchy grain. It is the second largest cereal cultivated worldwide and staple food for almost 60 per cent of the global population. Due to the increased population, the demand for rice is expected to rise by 38 per cent within 30 years (Satyanarayana, 2005). The per capita availability of paddy in Asia has decreased from $54.7 \mathrm{~kg}$ in 2001 to $53.9 \mathrm{~kg}$ in 2019 (FAOSTAT, 2019).

The success of System of Rice Intensification (SRI) cultivation practices has been shown in over 50 countries, including the major rice producers in the world such as China, Vietnam, Cambodia and Philippines (Katambara et al., 2013) as well as in India (Thakur et al., 2013). However, due to wider spacing with lesser plant population per square metre in the SRI method, forcing the existing plants to produce more tillers. Hence, Modified SRI (MSRI) is one option in which the certain modifications are made in any of the principles or in management practices of SRI using best scientific knowledge for the benefit of farmers to get maximum yield and to adapt the local agro-ecological climatic condition (Thakur et al., 2016). Increasing of production by way of reducing population, by following all SRI practices is one such modification which may increase the number of panicle $/ \mathrm{m}^{2}$ and in turn yield of rice.

Physiological parameters like photosynthetic rate, transpiration rate and stomatal conductance are highly influenced by planting density and also by climatic factors. Grain yield in rice is influenced by balance 
between respiration and photosynthesis and a key physiological parameter affected by the planting density and microclimate (Centritto et al., 2009). Most of the carbon stored in the mature rice grains originates from $\mathrm{CO}_{2}$ assimilation during the grain filling period is determined by the process of $\mathrm{CO}_{2}$ assimilation in rice. Factors that lower the photosynthesis rate of the flag leaf during this period could affect the grain yield in rice. Lesser soil temperature affects the stomatal conductance and assimilation rate, which affects the plant growth (Dingkuhn et al., 1989). The photosynthetic rate is more in rice following SRI method while comparing with the conventional method of cultivation (Hidayathi et al., 2016). Since, in rice leaf appearance is controlled by temperature near the apical meristem and the optimum leaf temperature $2^{\circ} \mathrm{C}$ lower than the optimum air temperature affects phenological development (Ellis et al., 1993).

However, there are limited studies on physiological parameters under high density condition. Hence, this research was conducted to evaluate the effects of high density planting on the rice plant's physiological parameters, namely photosynthetic rate, transpiration rate, stomatal conductance, chlorophyll index and leaf temperature of rice in response to high density planting with $\mathrm{SRI}$ principles, comparing these with conventional rice cultivation methods.

\section{MATERIALS AND METHODS}

\section{Location}

A field investigation was carried out during the late Samba season of 2018-19 (September 2018 to January 2019) at Wetland farms of the Department of Agronomy, Tamil Nadu Agricultural University, Coimbatore. The experimental site was situated in Semi-arid tropics of south India. Geographically, Coimbatore Western Agroclimatic zone at $11^{\circ} 83^{\prime} \mathrm{N}$ latitude, $76^{\circ} 71^{\prime} \mathrm{E}$ longitude is with an elevation of $426.7 \mathrm{~m}$ above mean sea level (MSL).

\section{Soil characteristics}

The soil of the experimental field was clay loam in texture with $\mathrm{pH}$ and $\mathrm{EC}$ of 8.2 and $0.5 \mathrm{dS} / \mathrm{m}$, respectively. The nutrient status of the soil during the start of the experiment was low in nitrogen $(22.68 \mathrm{~kg} / \mathrm{ha})$, medium in phosphorous (19.25 kg/ha) and high in potassium (571.1 kg/ha) with an organic carbon content of about $12.12 \mathrm{~g} / \mathrm{kg}$ of soil.

\section{Experimental details}

The study was conducted using randomized complete block design having three replications. The treatments viz., $\mathrm{T}_{1}-25 \times 25 \mathrm{~cm}+100 \%$ RDF (Recommended dosage of fertilizer) (SRI), $\mathrm{T}_{2}-25 \times 20 \mathrm{~cm}+100 \% \mathrm{RDF}, \mathrm{T}_{3}$ $-25 \times 15 \mathrm{~cm}+100 \% \mathrm{RDF}, \mathrm{T}_{4}-25 \times 15 \mathrm{~cm}+125 \%$
RDF, $\mathrm{T}_{5}-20 \times 20 \mathrm{~cm}+100 \% \mathrm{RDF}, \mathrm{T}_{6}-20 \times 15 \mathrm{~cm}+$ $100 \%$ RDF, $T_{7}-20 \times 15 \mathrm{~cm}+125 \%$ RDF) follows System of rice intensification (SRI) principles and $\mathrm{T}_{8}$ - Conventional cultivation. Latest released rice variety from TNAU, Rice CO-52 with the field duration of 130-135 days was used in this field experiment.

\section{Crop cultivation practices}

Mat nursery was prepared for raising seedlings for $T_{1}$ $\mathrm{T}_{7}$ treatments and conventional nursery for conventional method of planting $\left(T_{8}\right)$. The main field was prepared by puddling and then, the buds were trimmed and plastered. The layout was taken as per treatment schedule after levelling the fields using a wooden leveller. The bunds were formed and seedlings were transplanted at 14 DAS for $T_{1}-T_{7}$ treatments and 30 DAS for treatment. Recommended dose of fertilizers (150: $50: 50 \mathrm{~kg} \mathrm{~N}$ : $\mathrm{P}_{2} \mathrm{O}_{5}: \mathrm{K}_{2} \mathrm{O} / \mathrm{ha}$ ) were applied as urea, single super phosphate and muriate of potash to all the plots as per the treatment. Nitrogen and potassium were given in four equal split doses at basal, active tillering (50 DAT), panicle initiation (70 DAT) and flowering stages (100 DAT). A full dosage of phosphorus, 25 per cent of nitrogen and potassium were applied as basal prior to transplanting. Top dressing of nitrogen was done based on LCC observations in all plots. Excluding the conventional cultivation plots, weeding operation was done on $15,25,35$ and 45 DAT using hand operated rotary weeder in both direction for square planted plots, while in one direction in all other plots. All other practices were followed as per Crop Production Guide (2012).

\section{Measurement of physiological parameters}

Physiological parameters like photosynthetic rate, transpiration rate and stomatal conductance were measured using Portable Photosynthetic System (PPS) - Model LCi-SD of ADC BioScientific Ltd., Great Amwell, Hertfordshire, UK. Rice leaf was inserted in a broad leaf chamber $\left(6.25 \mathrm{~cm}^{2}\right)$ and the leaf area was set at $3.26 \mathrm{~cm}^{2}$. Using the above PPS system, the observations were made at active tillering, panicle initiation, flowering and at maturity stages of rice from the third uppermost leaf at randomly selected five plants and calculated the mean value for each parameter.

Leaf temperature $\left({ }^{\circ} \mathrm{C}\right)$ was measured on top unfolded leaves of rice in individual plots using infrared thermometer (Foopro, Raytek, USA). The time of observations was $0600 \mathrm{hrs}, 1000 \mathrm{hrs}, 1400 \mathrm{hrs}$ and $1800 \mathrm{hrs}$ and the observation were made at weekly interval viz., 41 DAT, 48 DAT, 55 DAT, 62 DAT, 69 DAT, 76 DAT, 83 DAT, 90 DAT, 97 DAT, 104 DAT and 111 DAT.

Chlorophyll index was measured with SPAD meter (Model 502, Spectrum Technologies, Inc.). The readings were taken in the third uppermost leaf from randomly selected five plants and calculated the mean value at active tillering, panicle initiation, flowering and 
maturity stages.

\section{Measurement of grain yield}

The crop was harvested upon harvesting stage. The border rows in the plots were removed from the field. The net plot was then harvested, hand threshed, sun dried and weighed and allowed to 14 per cent moisture content. The grain yield was converted to $\mathrm{kg} / \mathrm{ha}$.

\section{Statistical analysis}

The data collected from field experiment at different growth stages were statistically analysed for Least Square Difference (LSD) at 5 per cent probability level as described by Gomez and Gomez (2010). The correlation analysis was done using $\mathrm{R}$ studio programming with statistical packages (RStudio, 2015).

\section{RESULTS AND DISCUSSION}

\section{Effect of high density planting on photosynthetic rate of rice}

The photosynthetic rate was altered significantly during each growth stages of rice under high density planting are presented in Table 1.

At the active tillering stage, significantly (at $5 \%$ level) higher photosynthetic rate $\left(24.6 \mu \mathrm{mol} \mathrm{CO}_{2} / \mathrm{m}^{2} / \mathrm{s}\right)$ was noted in plant spacing level of $25 \times 25 \mathrm{~cm}$ with $100 \%$ RDF $\left(T_{1}\right)$ compared to all other treatments under testing but, it was on par with planting spacing of $25 \times 20$ $\mathrm{cm}$ with $100 \% \operatorname{RDF}\left(24.3 \mu \mathrm{mol} \mathrm{CO}_{2} / \mathrm{m}^{2} / \mathrm{s}\right)$. A significantly lesser photosynthetic rate $\left(21.8 \mu \mathrm{mol} \mathrm{CO}_{2} / \mathrm{m}^{2} / \mathrm{s}\right)$ was recorded in the conventional method of planting $\left(T_{8}\right)$. Similarly, at the panicle initiation stage, the plant with a spacing of $25 \times 25 \mathrm{~cm}$ with $100 \% \operatorname{RDF}\left(\mathrm{T}_{1}\right)$ registered significantly higher photosynthetic values $(28.3 \mu \mathrm{mol}$ $\mathrm{CO}_{2} / \mathrm{m}^{2} / \mathrm{s}$ ) compared to other treatments. The least values on photosynthetic rate $\left(23.6 \mu \mathrm{mol} \quad \mathrm{CO}_{2} / \mathrm{m}^{2} / \mathrm{s}\right)$ was recorded in conventional method of planting $\left(\mathrm{T}_{8}\right)$. At flowering and maturity stages also, the same trend was noticed. By correlation analysis, photosynthetic rate is positively correlated with yield but not significantly. By regression fit analysis, a close relationship was observed between photosynthetic rate and observed chlorophyll index (Fig. 1). The photosynthetic rate depends upon the plant canopy structure which influences the amount of light profile absorbed by the leaf (Weiss et al., 2004). Hence, higher photosynthetic rate in lower planting density was due to wider canopy structure and angle, broadly spreaded tillers and erect leaves, which reduced the self-shading to bottom leaf and mutual shading of leaves and enhanced better light utilization by the canopy (Hidayati et al., 2016). However, the photosynthetic rate is also depends on light energy absorbed by the chlorophyll (Maxwell and Johnson, 2000). Chlorophyll content is closely related to photosynthetic rate, because it provides the photosynthetic apparatus which allows plants to absorb energy from light and transfer it to the chlorophyll (Porra et al., 1993). With a higher amount of chlorophyll in the leaves, a higher photosynthesis rate can be maintained (Kura-Hotta et al., 1987). From this study also, higher chlorophyll index was noticed in wider spacing compared to denser plant spacing. Lower photosynthetic rate was noted in denser plant spacing, was mainly due to the production of narrow leaves that reduces the sunlight absorption by leaves led to

Table 1. Effect of high density planting on physiological parameters of rice at different stages.

\begin{tabular}{|c|c|c|c|c|c|c|c|c|c|c|c|c|}
\hline \multirow[t]{2}{*}{ Treatments } & \multicolumn{4}{|c|}{$\begin{array}{l}\text { Photosynthetic rate } \\
\qquad\left(\mu \mathrm{mol} \mathrm{CO} \mathrm{CO}_{2} / \mathrm{m}^{2} / \mathrm{s}\right)\end{array}$} & \multicolumn{4}{|c|}{$\begin{array}{l}\text { Transpiration rate } \\
\left(\mathrm{mmol} \mathrm{H}_{2} \mathrm{O} / \mathrm{m}^{2} / \mathrm{s}\right)\end{array}$} & \multicolumn{4}{|c|}{$\begin{array}{l}\text { Stomatal conductance } \\
\left(\mathrm{mol} \mathrm{H} \mathrm{H}_{2} \mathrm{O} / \mathrm{m}^{2} / \mathrm{s}\right)\end{array}$} \\
\hline & AT & PI & FL & MT & AT & PI & FL & MT & AT & PI & FL & MT \\
\hline $\mathrm{T}_{1}$ & 24.63 & 28.30 & 34.73 & 18.33 & 7.55 & 7.90 & 9.64 & 6.37 & 0.173 & 0.192 & 0.307 & 0.143 \\
\hline $\mathrm{T}_{2}$ & 24.33 & 26.17 & 34.00 & 17.23 & 7.53 & 7.66 & 9.50 & 6.13 & 0.167 & 0.189 & 0.301 & 0.144 \\
\hline $\mathrm{T}_{3}$ & 23.10 & 25.63 & 32.53 & 16.90 & 7.49 & 7.56 & 9.45 & 5.63 & 0.165 & 0.187 & 0.294 & 0.137 \\
\hline $\mathrm{T}_{4}$ & 23.13 & 25.77 & 32.83 & 16.73 & 7.41 & 7.66 & 9.38 & 5.87 & 0.167 & 0.186 & 0.299 & 0.137 \\
\hline $\mathrm{T}_{5}$ & 22.17 & 25.13 & 32.57 & 16.47 & 6.63 & 7.59 & 9.28 & 5.60 & 0.150 & 0.173 & 0.289 & 0.130 \\
\hline $\mathrm{T}_{6}$ & 22.77 & 24.73 & 31.80 & 16.83 & 6.84 & 7.51 & 8.79 & 5.57 & 0.150 & 0.168 & 0.280 & 0.127 \\
\hline $\mathrm{T}_{7}$ & 22.57 & 23.80 & 32.03 & 16.50 & 6.66 & 7.59 & 8.78 & 5.57 & 0.157 & 0.166 & 0.264 & 0.130 \\
\hline $\mathrm{T}_{8}$ & 21.77 & 23.60 & 31.67 & 16.20 & 6.63 & 7.04 & 8.73 & 5.47 & 0.147 & 0.162 & 0.238 & 0.127 \\
\hline SEd & 0.15 & 0.07 & 0.16 & 0.07 & 0.07 & 0.06 & 0.14 & 0.19 & 0.004 & 0.005 & 0.006 & 0.003 \\
\hline $\begin{array}{l}\text { CD at } 5 \% \\
\text { level }\end{array}$ & 0.33 & 0.15 & 0.34 & 0.15 & 0.15 & 014 & 0.29 & 0.42 & 0.009 & 0.012 & 0.013 & 0.007 \\
\hline
\end{tabular}

AT - Active tillering; PI - Panicle initiation; FL - Flowering stage; MT - Maturity stage; $\mathrm{T}_{1}-25 \times 25 \mathrm{~cm}$ with $100 \% \mathrm{RDF}$ (SRI); $\mathrm{T}_{2}-25 \times$ $20 \mathrm{~cm}$ with $100 \%$ RDF; T $-25 \times 15 \mathrm{~cm}$ with $100 \%$ RDF; $\mathrm{T}_{4}-25 \times 15 \mathrm{~cm}$ with $125 \%$ RDF; T $-20 \times 20 \mathrm{~cm}$ with $100 \%$ RDF; T 6 - $20 \times 15$ $\mathrm{cm}$ with $100 \% \mathrm{RDF} ; \mathrm{T}_{7}-20 \times 15 \mathrm{~cm}$ with $125 \%$ RDF; $\mathrm{T}_{8}-$ Conventional cultivation with $100 \%$ RDF 


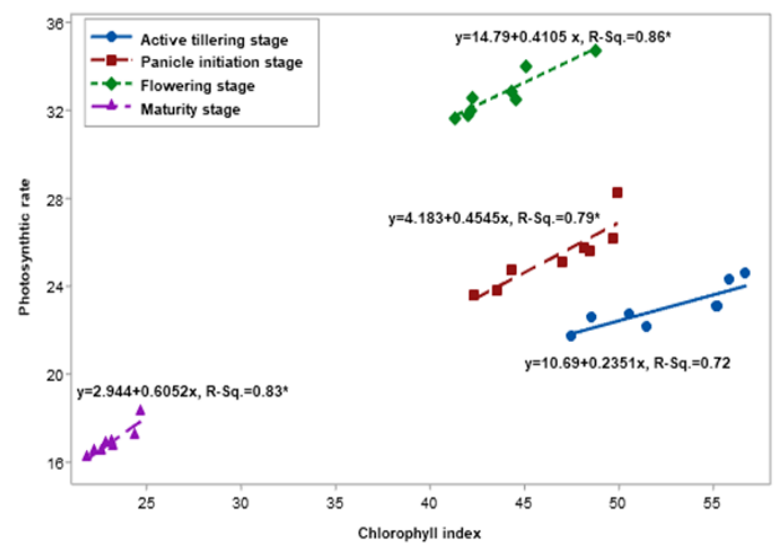

Fig. 1. Relationship between photosynthetic rate and chlorophyll index of rice at different stages. ( ${ }^{*}$ significant at $5 \%$ level).

reduced chlorophyll content in leaves that ultimately reduces the photosynthetic rate. Similar results were reported by San-oh et al. (2006) and Thakur et al. (2010).

\section{Effect of high density planting on transpiration rate of rice}

Mean data obtained on transpiration rate $\left(\mathrm{mmol} \mathrm{H}_{2} \mathrm{O}\right.$ / $\mathrm{m}^{2} / \mathrm{s}$ ) of rice at active tillering, panicle initiation, flower- ing and at maturity stages are given under Table 1.

At the active tillering stage, the transpiration rate was varied significantly due to high density planting. The rice planted at a spacing of $25 \times 25 \mathrm{~cm}$ with $100 \% \mathrm{RDF}$ $\left(\mathrm{T}_{1}\right)$ recorded a significantly higher rate of transpiration ( $7.55 \mathrm{mmol} \mathrm{H}_{2} \mathrm{O} / \mathrm{m}^{2} / \mathrm{s}$ ) but, it was statistically on par with a spacing of $25 \times 20 \mathrm{~cm}$ with $100 \%$ RDF $(7.53$ $\mathrm{mmol} \mathrm{H}_{2} \mathrm{O} / \mathrm{m}^{2} / \mathrm{s}$ ) and $25 \times 15 \mathrm{~cm}$ fertilized with $100 \%$ RDF $\left(7.49 \mathrm{mmol} \mathrm{H}_{2} \mathrm{O} / \mathrm{m}^{2} / \mathrm{s}\right)$ and $20 \times 20 \mathrm{~cm}$ spacing with $100 \% \operatorname{RDF}\left(\mathrm{T}_{5}\right)$. All other spacing levels recorded a lower transpiration rate with the minimum of 6.63 $\mathrm{mmol} \mathrm{H}_{2} \mathrm{O} / \mathrm{m}^{2} / \mathrm{s}$ recorded in conventional method transplanting $\left(T_{8}\right)$. During panicle initiation stage, significantly higher rate of transpiration rate values $(7.90 \mathrm{mmol}$ $\mathrm{H}_{2} \mathrm{O} / \mathrm{m}^{2} / \mathrm{s}$ ) were recorded at spacing $25 \times 25 \mathrm{~cm}$ with $100 \% \operatorname{RDF}\left(T_{1}\right)$ than others. Lower transpiration rate ( $7.04 \mathrm{mmol} \mathrm{H} \mathrm{H}_{2} \mathrm{O} / \mathrm{m}^{2} / \mathrm{s}$ ) was observed in rice planted at conventional method of planting $\left(\mathrm{T}_{8}\right)$. At flowering stage, higher transpiration $\left(9.64 \mathrm{mmol} \mathrm{H}_{2} \mathrm{O} / \mathrm{m}^{2} / \mathrm{s}\right)$ was noted at spacing of $25 \times 25 \mathrm{~cm}$ with $100 \% \operatorname{RDF}\left(\mathrm{T}_{1}\right)$ but it was on par with other $25 \mathrm{~cm}$ row spacing levels $\left(\mathrm{T}_{2}\right.$, $\mathrm{T}_{3}$ and $\mathrm{T}_{4}$ ). Significantly lower transpiration rate (8.73 mmol $\mathrm{H}_{2} \mathrm{O} / \mathrm{m}^{2} / \mathrm{s}$ ) was observed at conventional method of planting $\left(\mathrm{T}_{8}\right)$ and was par at $20 \times 15 \mathrm{~cm}$ applied with $100 \% \operatorname{RDF}\left(\mathrm{T}_{6}\right)$ and $125 \% \operatorname{RDF}\left(\mathrm{T}_{7}\right)$. Wider plant spacing $(25 \times 25 \mathrm{~cm}$ and $25 \times 20 \mathrm{~cm})$ with $100 \% \operatorname{RDF}\left(\mathrm{T}_{1}\right.$ and $T_{2}$ ) did record significantly higher transpiration rate
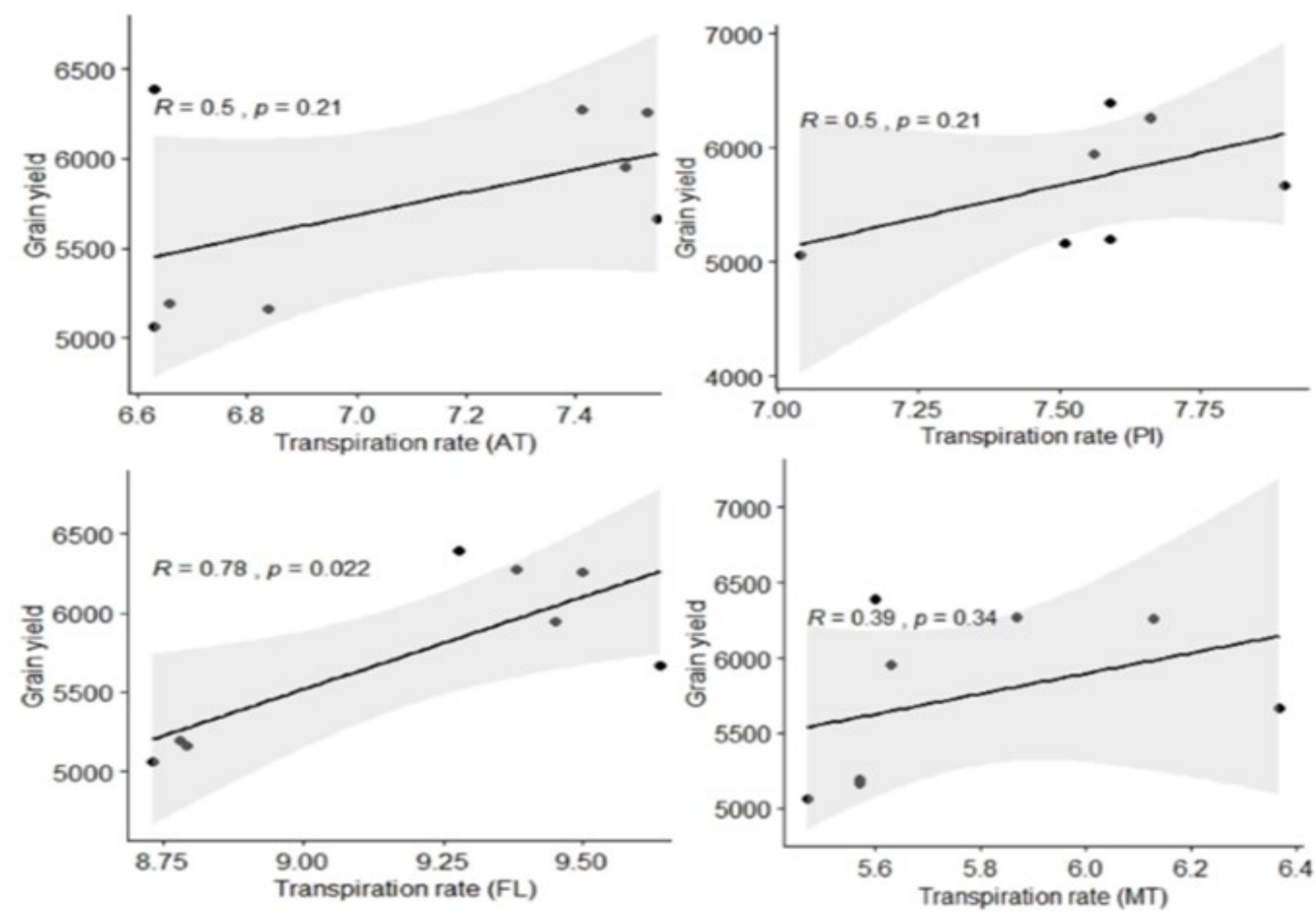

Fig. 2. Transpiration rate vs grain yield of rice at different stages. AT- Active tillering stage, PI- Panicle initiation stage, FL- Flowering stage, MT- Maturity stage. (Scatter plot with correlation analysis). 

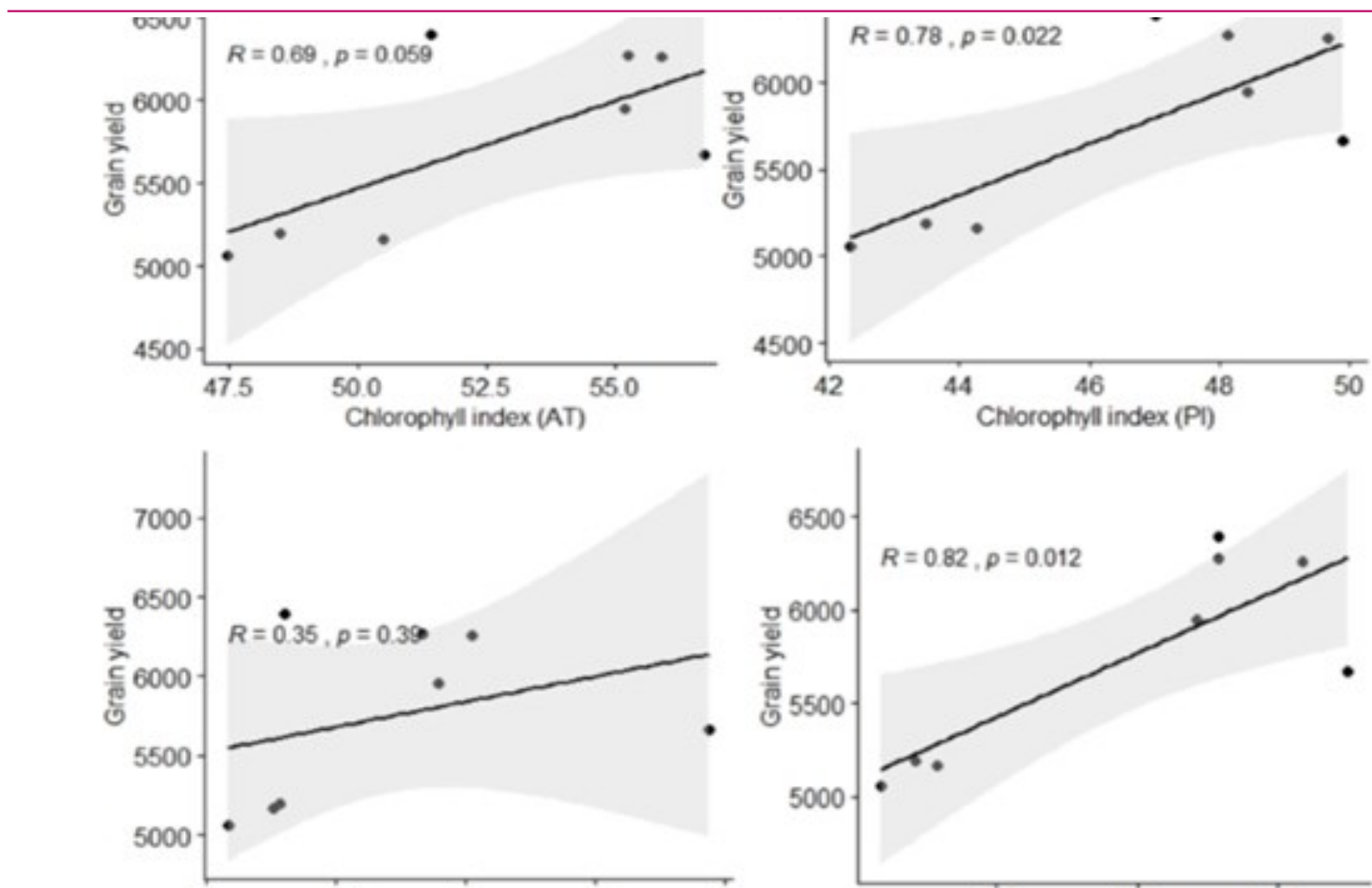

Fig. 3. Stomatal conductance vs grain yield of rice at different stages. AT- Active tillering stage, PI- Panicle initiation stage, FL- Flowering stage, MT- Maturity stage. (Scatter plot with correlation analysis).

(6.37 and $6.13 \mathrm{mmol} \mathrm{H}_{2} \mathrm{O} / \mathrm{m}^{2} / \mathrm{s}$, respectively) compared to all other treatments which were statistically on par with each other with the least transpiration rate $(5.47$ $\mathrm{mmol} \mathrm{H}_{2} \mathrm{O} / \mathrm{m}^{2} / \mathrm{s}$ ) in conventional method of planting $\left(\mathrm{T}_{8}\right)$. The correlation analysis shows that transpiration rate influenced positively on the grain yield obtained and significantly correlated during the flowering stage $\left(r=0.78^{*}\right)$ of rice (Fig. 2). In wider spacing, the plant leaves are more exposed to sunlight due to lesser LAI and sparse crop canopy, which might have allowed the sunlight to fall on most of the leaves and would have enhanced the transpiration rate. The reason was due to the mutual shading of leaves due to dense canopy and higher LAI, which might not allow the sunrays to fall and penetrate to all leaves in closer spacing treatments. Wind speed form a thick lower boundary layer around the leaves which might reduce the transpiration rate in denser planting. This result is in agreement with the result by Farooq et al. (2009).

\section{Effect of high density planting on stomatal conductance of rice}

The stomatal conductance $\left(\mathrm{mol} \mathrm{H}_{2} \mathrm{O} / \mathrm{m}^{2} / \mathrm{s}\right)$ of rice as influenced by high density planting at active tillering, panicle initiation, flowering and maturity stages are represented in the Table 1.

At active tillering stage, the plants at a spacing level of $25 \times 25 \mathrm{~cm}$ with $100 \% \operatorname{RDF}\left(\mathrm{T}_{1}\right)$ recorded significantly higher values $\left(0.173 \mathrm{~mol} \mathrm{H}_{2} \mathrm{O} / \mathrm{m}^{2} / \mathrm{s}\right)$ but, it was on par

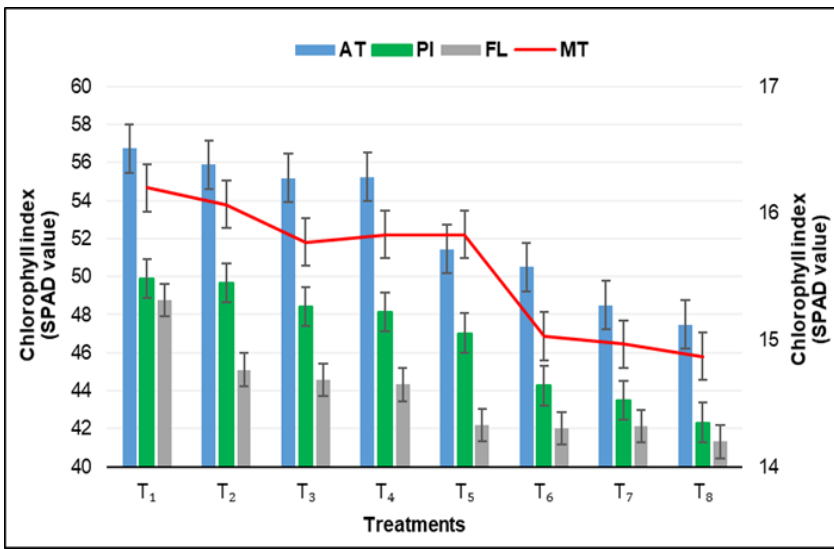

Fig. 4. Effect of high density on chlorophyll index of rice. AT- Active tillering stage, PI- Panicle initiation stage, FLFlowering stage, MT- Maturity stage. (The vertical line in bar chart represents standard error).

with other wider spacing levels $(25 \times 20 \mathrm{~cm}$ and $25 \times$ $15 \mathrm{~cm})$ with $100 \% \operatorname{RDF}$ and $125 \% \operatorname{RDF}\left(T_{2}, T_{3}\right.$ and $\left.T_{4}\right)$. Significantly lesser stomatal conductance $(0.147 \mathrm{~mol}$ $\mathrm{H}_{2} \mathrm{O} / \mathrm{m}^{2} / \mathrm{s}$ ) was observed in spacing of $20 \times 10 \mathrm{~cm}$ with $100 \%$ RDF and was on par with all the row spacing levels of $20 \mathrm{~cm}\left(T_{5}, T_{6}\right.$ and $\left.T_{7}\right)$ with any of nutrient level. Similar trend of observation as like active tillering stage was recorded during panicle initiation and maturity stages. At flowering stage, significantly higher values ( $0.30 \mathrm{~mol} \mathrm{H} \mathrm{H}_{2} \mathrm{O} / \mathrm{m}^{2} / \mathrm{s}$ ) of stomatal conductance were noted in $25 \times 25 \mathrm{~cm}$ spacing level with $100 \% \operatorname{RDF}\left(T_{1}\right)$, but it was statistically on par with level of spacing levels of 

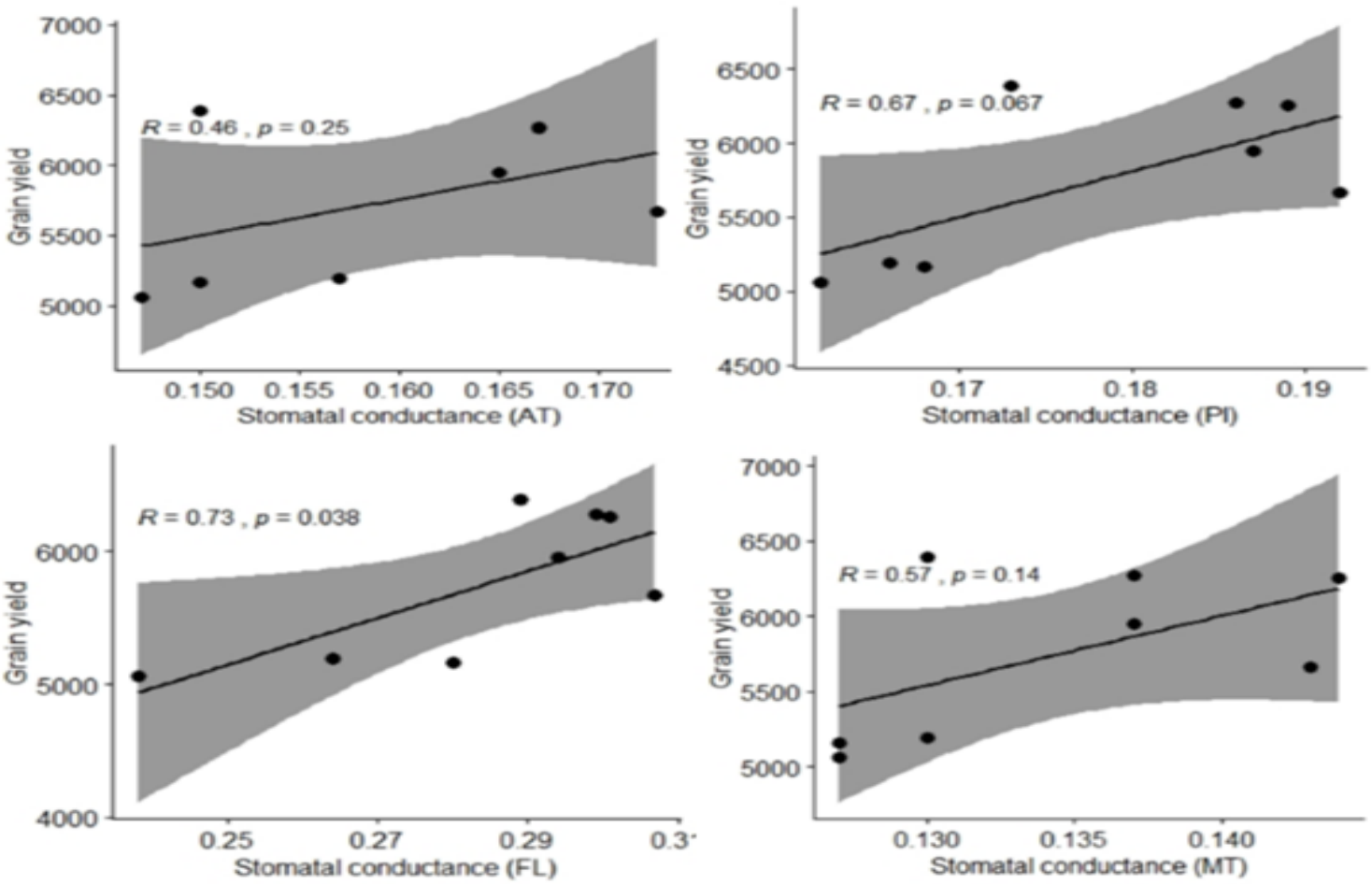

Fig. 5. Chlorophyll index vs grain yield of rice at different stages. AT- Active tillering stage, Pl- Panicle initiation stage, FL - Flowering stage, MT- Maturity stage. (Scatter plot with correlation analysis).

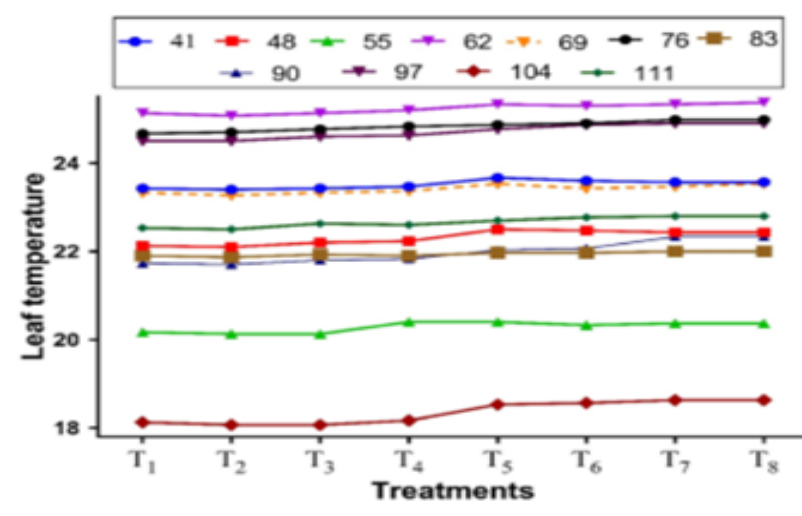

A) $0600 \mathrm{hrs}$

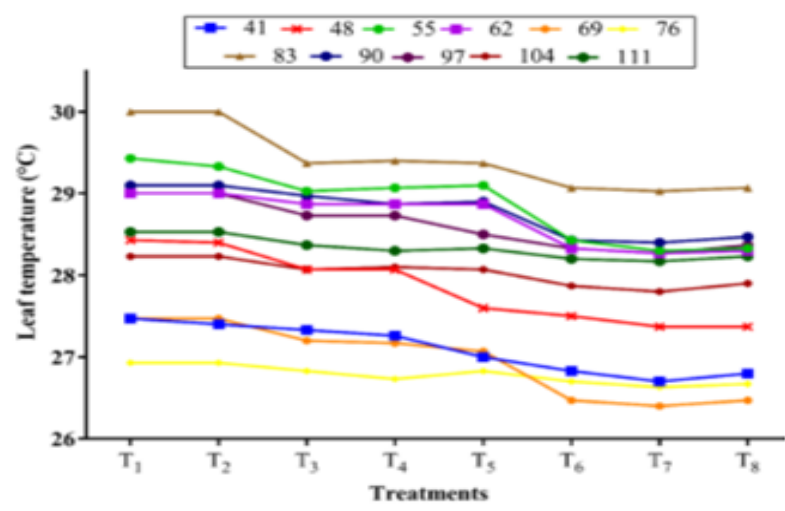

C) $1400 \mathrm{hrs}$

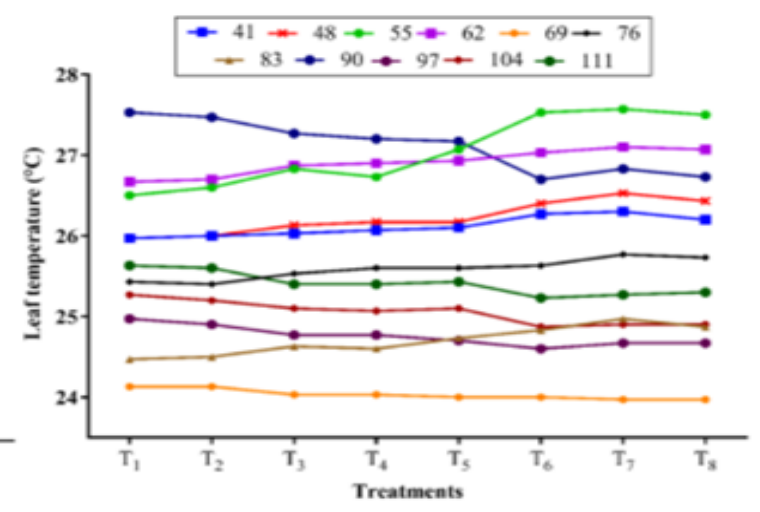

B) $1000 \mathrm{hrs}$

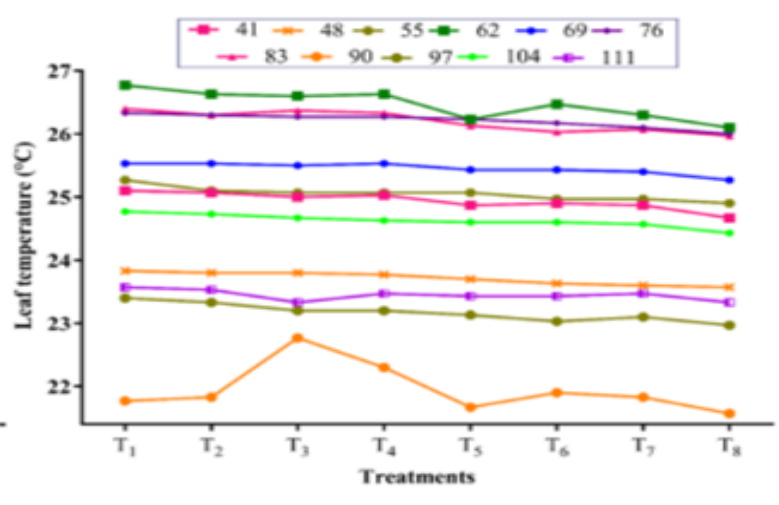

D) $1800 \mathrm{hrs}$

Fig. 6. Weekly leaf temperature at different time intervals at $0600 \mathrm{hrs}, 1000 \mathrm{hrs}, 1400 \mathrm{hrs}$ and $1800 \mathrm{hrs}$. 
$25 \times 20 \mathrm{~cm}$ with $100 \% \operatorname{RDF}\left(\mathrm{T}_{2}\right), 25 \times 15 \mathrm{~cm}$ with $100 \% \operatorname{RDF}\left(\mathrm{T}_{4}\right)$ and $125 \% \operatorname{RDF}\left(\mathrm{T}_{5}\right)$. Significantly lower value on stomatal conductance $\left(0.238 \mathrm{~mol} \mathrm{H}_{2} \mathrm{O} / \mathrm{m}^{2} / \mathrm{s}\right)$ was recorded in conventional method of planting than all others. Stomatal conductance at flowering stage was positively and significantly correlated to the grain yield obtained $\left(r=0.73^{*}\right)$ (Fig. 3). In general, stomatal conductance was more in wider spacing than closer spacing during all stages. The reason for higher stomatal conductance in wider spacing was due to more light profile at canopy level with higher temperature and lesser relative humidity as evidenced in the present study which might have promoted the stomata to open. However, lesser stomatal conductance was observed in closer spacing, due to partially closed stomata by low illumination level of light caused by mutual shading of leaves (Farooq et al., 2010). Accumulation of more humidity due to denser canopy structure also expressed to universe relationship between relative humidity and stomatal conductance (Nobel, 1999).

\section{Effect of high density planting on chlorophyll index of rice}

The chlorophyll index (SPAD value) during active tillering, panicle initiation, flowering and maturity stages are given in Figure 4. During the active tillering stage, significantly higher SPAD value (56.73) were recorded at spacing of $25 \times 25 \mathrm{~cm}$ with $100 \% \operatorname{RDF}\left(\mathrm{T}_{1}\right)$ than all other treatments. Conventional method of planting recorded the lowest chlorophyll index value (47.47). At the panicle initiation stage, rice planted at a spacing of 25 $\times 25 \mathrm{~cm}$ with 100\% RDF $\left(\mathrm{T}_{1}\right)$ recorded higher chlorophyll index (49.90) over other treatment under study, however, it was on par with $25 \times 20 \mathrm{~cm}$ with $100 \%$ RDF $\left(T_{2}\right)$. Almost similar nature of results were noted at later (flowering and maturity) stages also. A positive correlation between grain yield and chlorophyll index at panicle initiation $\left(r=0.78^{*}\right)$ and flowering stages

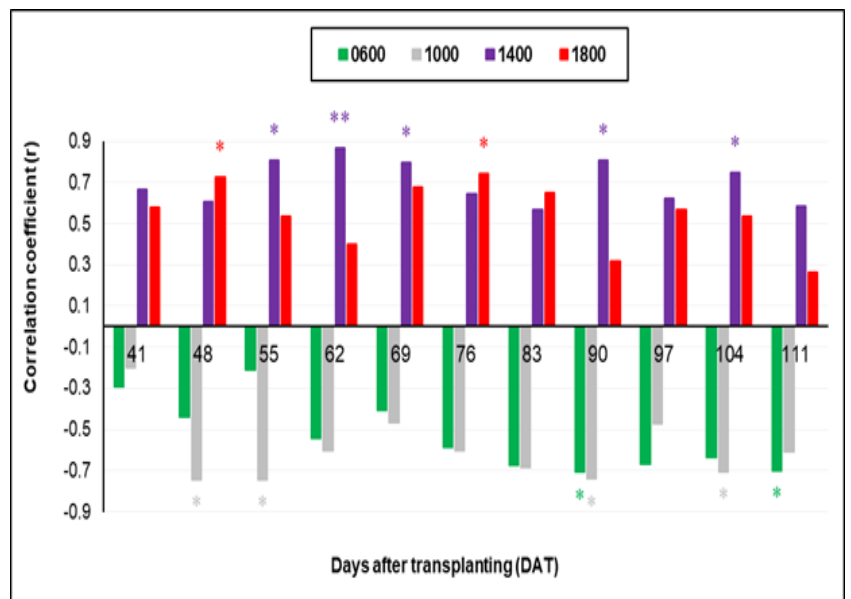

Fig. 7. Correlation between leaf temperature and grain yield at weekly intervals ( ${ }^{*}$ significant at $5 \%$ level ${ }^{* *}$ significant at $1 \%$ level). $\left(r=0.82^{*}\right)$ was recorded and is represented in Fig. 5. During all the stages, the chlorophyll index was significantly higher in wider plant spacing. This might be due to more spacing (lesser plant population), more solar radiation is observed by plant leaves which might increase the chlorophyll index in wider spacing plants. The lower value is due to mutual shading and denser plant population.

\section{Effect of high density planting on leaf temperature of rice}

Weekly leaf temperature recorded at different time intervals viz., $0600 \mathrm{hrs}, 1000 \mathrm{hrs}, 1400 \mathrm{hrs}$ and $1800 \mathrm{hrs}$ are represented in Fig. 6. At $0600 \mathrm{hrs}$ and $1000 \mathrm{hrs}$, closer spacing levels $\left(T_{5}, T_{6}, T_{7}\right.$ and $\left.T_{8}\right)$ had higher leaf temperature during all time of weekly observation, while during later time of observation (1400 hrs and 1800 $\mathrm{hrs}$ ), warmer leaf temperature $(\square)$ was noted in wider spacing levels ( $T_{1}$ and $T_{2}$ ) over other treatments. In general, leaf temperature was higher in closer spacing compared to wider spacing at $0600 \mathrm{hrs}$. In closer spacing, where heat trapped inside the canopy during night hours might reflect on leaf surface as high leaf temperature at early hours. During $1000 \mathrm{hrs}, 1400 \mathrm{hrs}$ and $1800 \mathrm{hrs}$, wider spacing plants had more leaf temperature compared to closer spacing levels. The reason for warmer leaf surface in wider spacing treatments might be due to leaves of rice are more exposed to solar radiation, which would absorb the solar radiation as heat. The plants with lesser leaves can be easily heated than more leaves, hence lesser leaves in wider spacing, the leaf surface was high (Yang et al., 2014). However, leaf structure and orientation play an important role in leaf temperature (Nobel, 1999). Cooler leaf temperature was recorded in closer spacing levels was mainly due to poor light illumination at lower level leaves which cause leaf surface cooler in rice. Correlation analysis between leaf temperature and grain yield shows negative

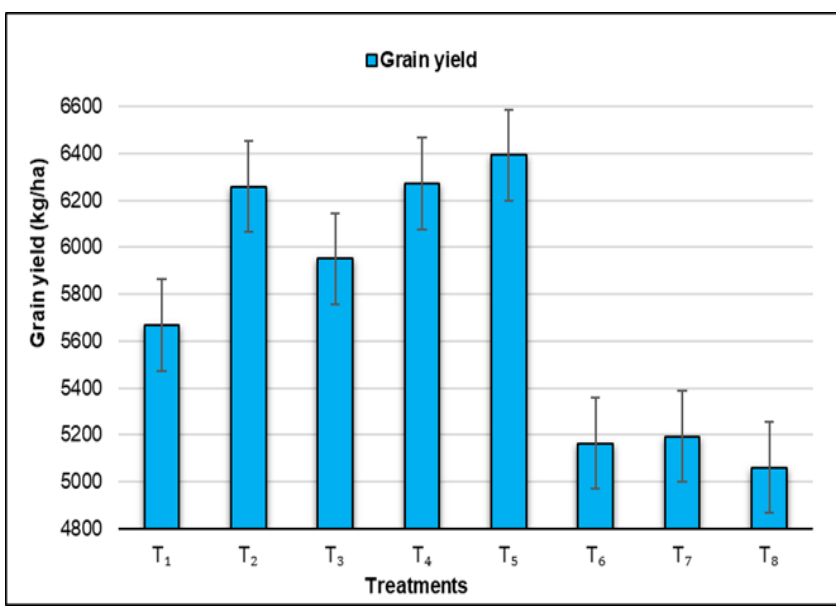

Fig. 8. Effect of high density planting on grain yield of rice. (The vertical line in bar chart represents standard error). 
response during $0600 \mathrm{hrs}$ and $1000 \mathrm{hrs}$, and positive response during $1400 \mathrm{hrs}$ and $1800 \mathrm{hrs}$ (Fig. 7).

\section{Influence of high density planting on yield of rice} Grain yield was significantly influenced due to plant spacing (Fig. 8). A significantly higher grain yield was recorded under $20 \times 20 \mathrm{~cm}(6392 \mathrm{~kg} / \mathrm{ha})$ planting geometry which was statistically on par with $25 \times 20 \mathrm{~cm}$ (6259 kg/ha), $25 \times 15 \mathrm{~cm}$ at 100\% RDF (5951 kg/ha) and $25 \times 15 \mathrm{~cm}$ at $125 \% \operatorname{RDF}(6272 \mathrm{~kg} / \mathrm{ha})$. The yields obtained under the rest of the plant spacing levels were lower and statistically identical. The lowest yield was recorded under conventional method of planting (5061 $\mathrm{kg} / \mathrm{ha}$ ). The reason for higher yield might be due to more plant population compared to wider spacing with optimum canopy temperature and reduced competition for light, air and nutrients compared to other spacing levels. Similar results by Thakur et al. (2010) also reported that rice plant at a spacing level of $20 \times 20 \mathrm{~cm}$ resulted in higher grain yield.

\section{Conclusion}

The study concluded that the photosynthetic rate, transpiration rate, stomatal conductance, and chlorophyll index were higher during the early growing period and decreased as rice grew at later stages. During all stages of rice, wider plant spacing levels had higher photosynthetic rate, transpiration rate, stomatal conductance and chlorophyll index, and also had positive correlation with the grain yield. Transpiration rate and stomatal conductance during the flowering stage significantly influenced the grain yield of rice. While leaf temperature was higher in closed spacing levels during 0600 and 1000 hours, a reversal trend was noticed during 1400 and 1800 hours. Grain yield shows a negative response during $0600 \mathrm{hrs}$ and $1000 \mathrm{hrs}$, and a positive response during $1400 \mathrm{hrs}$ and $1800 \mathrm{hrs}$ with observed leaf temperature. The optimum level of observation was noticed in planting spacing of $20 \times 20 \mathrm{~cm}$, which might result in higher grain yield.

\section{Conflict of interest}

The authors declare that they have no conflict of interest.

\section{REFERENCES}

1. Centritto, M., Lauteri, M., Monteverdi, M. C. \& Serraj, R. (2009). Leaf gas exchange, carbon isotope discrimination, and grain yield in contrasting rice genotypes subjected to water deficits during the reproductive stage. Journal of Experimental Botany, 60(8), 2325-2339. https://doi.org/1 0.1093/jxb/erp123.

2. Crop Production Guide (2012). Government of Tamil Nadu and Tamil Nadu Agricultural University, Coimbatore, Tamil Nadu.
3. Dingkuhn, M., De Datta, S. K., Dorffling, K., Javellana, C. \& Datta, S. (1989). Varietal differences in leaf water potential, leaf net $\mathrm{CO}_{2}$ assimilation, conductivity and water use efficiency in upland rice. Australian Journal of Agricultural Research, 40(6), 1183-1192.

4. Ellis, R. H., Qi, A., Summerfield, R. J. \& Roberts, E. H. (1993). Rates of leaf appearance and panicle development in rice (Oryza sativa L.): a comparison at three temperatures. Agricultural and Forest Meteorology, 66(3-4), 129-138. https://doi.org/10.1016/0168-1923(93)90066-Q.

5. Faostat (2019). Statistical databases. Food and Agriculture Organization of the United Nations

6. Farooq, M., Kobayashi, N., Ito, O., Wahid, A. \& Serraj, R. (2010). Broader leaves result in better performance of indica rice under drought stress. Journal of Plant Physiology, 167(13), 1066-1075. https://doi.org/10.1016/j.jplph.201 0.03.003.

7. Farooq, M., Wahid, A. \& Basra, S. M. A. (2009). Improving water relations and gas exchange with brassinosteroids in rice under drought stress. Journal of Agronomy and Crop Science, 195(4), 262-269.

8. Gomez, K. A. \& Gomez, A. A. (2010). Statistical procedures for agricultural research. John Wiley \& Sons.

9. Hidayati, N., Triadiati \& Anas, I. (2016). Photosynthesis and transpiration rates of rice cultivated under the system of rice intensification and the effects on growth and yield. HAYATI Journal of Biosciences, 23, 67-72. https:// doi.org/10.1016/j.hjb.2016.06.002.

10. Katambara, Z., Kahimba, F. C., Mahoo, H. F., Mbungu, W. B., Mhenga, F., Reuben, P. \& Nyarubamba, A. (2013). Adopting the system of rice intensification (SRI) in Tanzania: A review. Agricultural Sciences, 4, 369-375. https:// doi.org/10.4236/as.2013.48053.

11. Kura-Hotta, M., Satoh, K. \& Katoh, S. (1987). Relationship between photosynthesis and chlorophyll content during leaf senescence of rice seedlings. Plant and Cell Physiology, 28(7), 1321-1329. https://doi.org/10.1093/oxfordjour nals.pcp.a077421.

12. Maxwell, K. \& Johnson, G. N. (2000). Chlorophyll fluorescence-a practical guide. Journal of Experimental Botany, 51(345), 659-668. https://doi.org/10.1093/jexbot/51.3 45.659 .

13. Nobel, P. S. (1999). Physicochemical \& Environmental Plant Physiology. Academic press.

14. Porra, R. J., Schäfer, W., Cmiel, E., Katheder, I. \& Scheer, H. (1993). Derivation of the formyl-group oxygen of chlorophyll $b$ from molecular oxygen in greening leaves of a higher plant (Zea mays). FEBS Letters, 323(1-2), 31-34.

15. RStudio Team (2019). RStudio: Integrated Development for R. RStudio, Inc., Boston, MA. 2015. URL: https:// www.rstudio.com/products/rstudio.

16. San-oh, Y., Sugiyama, T., Yoshita, D., Ookawa, T. \& Hirasawa, T. (2006). The effect of planting pattern on the rate of photosynthesis and related processes during ripening in rice plants. Field Crops Research, 96(1), 113-124.

17. Satyanarayana, A. (2005). System of Rice Intensificationan innovative method to produce more with less water and inputs. Fourth IWMI-Tata Annual Partners' Meet, IRMA, Anand, India, February, 24-26.

18. Thakur, A. K., Rath, S., Roychowdhury, S. \& Uphoff, N. (2010). Comparative performance of rice with system of rice intensification (SRI) and conventional management 
using different plant spacings. Journal of Agronomy and Crop Science, 196(2), 146-159. https://doi.org/10.1111/j.1 439-037X.2009.00406.x.

19. Thakur, A. K., Rath, S. \& Mandal, K. G. (2013). Differential responses of system of rice intensification (SRI) and conventional flooded-rice management methods to applications of nitrogen fertilizer. Plant and Soil, 370(1), 59-71. https://doi.org/10.1007/s11104-013-1612-5.

20. Thakur, A. K., Kassam, A., Stoop, W. A. \& Uphoff, N. (2016). Modifying rice crop management to ease water constraints with increased productivity, environmental benefits, and climate-resilience. Agriculture, Ecosystems \& Environment, 235, 101-104. https://doi.org/10.1016/ j.agee.2016.10.011

21. Weiss, M., Baret, F., Smith, G. J., Jonckheere, I. \& Coppin, P. (2004). Review of methods for in situ leaf area index (LAI) determination: Part II. Estimation of LAI, errors and sampling. Agricultural and Forest Meteorology, 121(1-2), 37-53. https://doi.org/10.1016/j.agrformet.2 003.08.001.

22. Yang, G. Z., Luo, X. J., Nie, Y. C. \& Zhang, X. L. (2014). Effects of plant density on yield and canopy micro environment in hybrid cotton. Journal of Integrative Agriculture, 13(10), 2154-2163. https://doi.org/10.1016/S2 095-3119(13)60727-3. 